\title{
Substrate utilisation in a Mediterranean littoral fish community
}

\author{
E. Macpherson* \\ Instituto de Ciencias del Mar (CSIC), Paseo Joan de Borbó s/n, E-08039 Barcelona, Spain
}

\begin{abstract}
Substratum use and spatial relationships in a littoral fish assemblage (families Blenniidae, Tripterygiidae and Gobidael were studied along the coast of northeastern Spain. All the species considered displayed a clear preference for a specific substratum type, and that preference was unrelated to substratum availability in the environment. Both the number of species and species density were distinctly higher for blennies and threefin blennies at depths of less than $1 \mathrm{~m}$. Larger numbers of species and higher density levels were observed in areas where rock and blocks were abundant as opposed to areas in which sand, gravel, or Posidonia oceanica beds predominated. The gobiids, in contrast, did not exhibit any clear tendency over the depth range considered. The results on the disjunct distributions, changes in niche breadth values for sympatric and allopatric distributions of species pairs, and variations in niche breadth and overlap with species richness appear to suggest that substratum occupancy by most species has no adverse effect on the other species present.
\end{abstract}

KEY WORDS: Fish communities - Substratum type and use Resource partitioning - Littoral fishes Mediterranean Sea

\section{INTRODUCTION}

Studies on fish communities have established the importance of a variety of mechanisms affecting community structure (Ross 1986), including competition for space (Buchheim \& Hixon 1992), food (Grossman 1982), predation (Hixon 1991), or constraints on recruitment (Doherty 1991). The role of competition remains an issue of open debate in ecology (Roughgarden 1983, Strong 1983) and is commonly studied either by experiment or observation (Schoener 1983). Certain workers (e.g. Connell 1983) have pointed out the shortcomings of observational methods in discerning competition in natural communities and the need for experimental approaches to demonstrate species interactions. Nevertheless, observational studies remain essential tools for disproving or establishing the hypotheses on which to base subsequent experimental work, particularly in the case of highly diverse assemblages (Norton 1991).

\footnotetext{
- Present address: Centro de Estudios Avanzados de Blanes (CSIC), Cami de Santa Barbara s/n, E-17300 Blanes (Girona), Spain
}

Such a highly diverse assemblage exists in the littoral zone in the western Mediterranean Sea, comprising species of the families Blenniidae, Tripterygiidae, and Gobiidae. The members of this assemblage are closely associated with the seabed and are often the dominant fishes in these nearshore habitats (Gibson 1969). At depths of less than $20 \mathrm{~m}$ there are some 15 species of blennies (Blenniidae), 3 species of threefin blennies (Tripterygiidae), and 18 species of gobies (Gobiidae) (Miller 1986, Zander 1986a, b). A number of studies have been performed on such species in both the Mediterranean and the Atlantic (e.g. Koppel 1988, Kotrschal 1988, Santos \& Almada 1988, Illich \& Kotrschal 1990, Costello 1992, Wilkins \& Myers 1992, 1993), yet the factors responsible for species density and distribution remain poorly understood.

Mature males of such species defend well-defined territories in which nests containing the eggs produced during breeding encounters are located (Gibson 1969, Wirtz 1978, Koppel 1988). Many of these species, mainly blennies, are concentrated in or virtually restricted to the depth zone from 0 to $1 \mathrm{~m}$ (Illich \& Kotrschal 1990). The territorial nature and high density of individuals in the surface strip suggests that 
intraguild competition may be a determining factor in the interrelationships between these species.

The object of the present study was to establish substratum use by the members of this assemblage and to analyse species abundance patterns and relationships between such patterns and availability of substratum type via an observational approach. Studying such aspects as disjunct distribution and niche divergence among species will help furnish information on the influence of spatial competition in this assemblage (Alatalo et al. 1986, Llewellyn \& Jenkins 1987, Bennett 1990). Although other mechanisms besides competition may account for the patterns observed (Norton 1991), the patterns do provide an indication of the likelihood of competitive interactions between certain species and thus as to which species should be considered in subsequent experimental work designed to obtain confirmation.

\section{METHODS}

Study area. The study was carried out at 3 localities along the coast of northeastern. Spain: Port de la Selva, the Medes Islands, and Blanes (Fig. 1). The Medes Islands are a marine reserve, while the other 2 localities are unprotected. The substrata at the study localities are mostly rocky, with broad stretches of sand and rocky blocks; the sea grass Posidonia oceanica predominates from a depth of 5 to $10 \mathrm{~m}$.

The geological characteristics of the 3 localities differ (Medialdea et al. 1989, 1994) and regulate the forma-

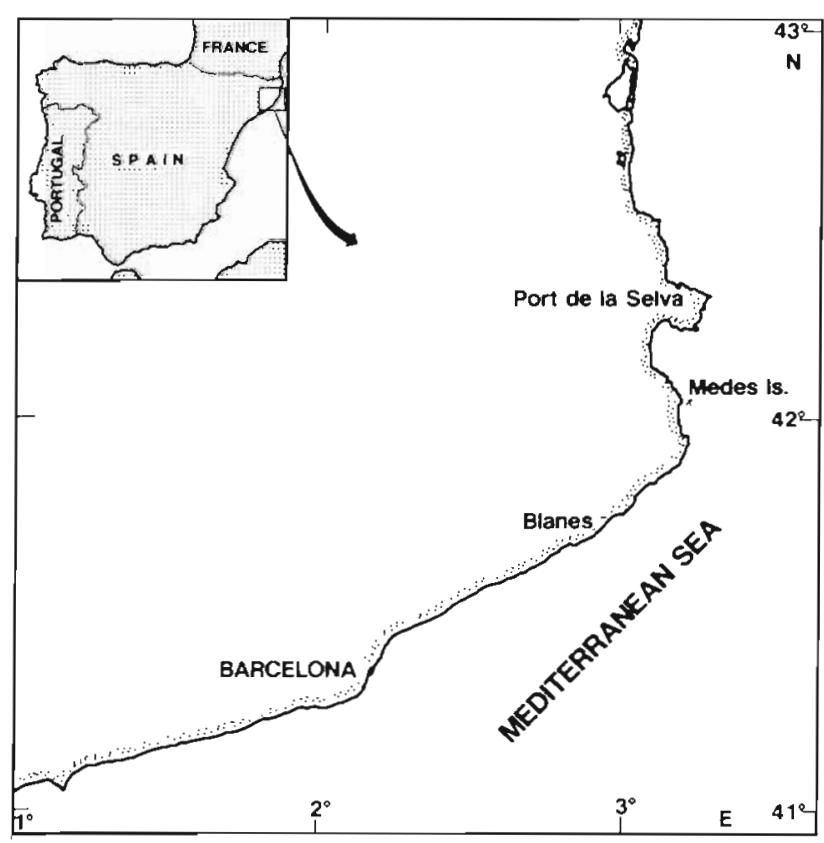

Fig. 1. Study area and location of sampling localities tion of holes and crevices in the rock which are commonly used by different blenniid species (Koppel 1988, Kotrschal 1988). Extremely hard igneous rock, predominately granite extensively eroded by wind and water, is common in the Port de la Selva area. These rocks contain numerous holes and crevices formed by erosion but very few holes excavated by endolithic bivalves. The Medes Islands are composed of softer limestone that contains many holes formed by endolithic bivalves. As around Port de la Selva, granite is also common in the Blanes area, but erosive forces there are weak and hence there are practically no holes produced by either endolithic bivalves or erosion.

Sampling procedure. Sampling was carried out by snorkeling and SCUBA diving from June to September 1993, when the species were most active (Kotrschal \& Reynolds 1982). Three separate sites between 200 and $1000 \mathrm{~m}$ apart were selected at Port de la Selva and the Medes Islands. At each site 4 horizontal transects from 30 to $92 \mathrm{~m}$ in length were laid out at depths of $0-1,5-6$, 10-11, and 15-16 m. At Blanes the same 4 transects were laid out at a single site only. The total sampling area was $1567 \mathrm{~m}^{2}$ along 28 transects. Every effort was made to ensure that all substratum types were represented on all transects. All sampling was carried out in the daytime on clear, cloudless days when the sea was calm.

A $1 \mathrm{~m}^{2}$ square frame was successively placed on the bottom along each transect. All individuals present in each such $1 \mathrm{~m}^{2}$ plot were recorded, along with the size and sex of those species with differing colouration in the 2 sexes (Zander 1986a, b, Abel 1993). In addition, the type of substratum occupied by each individual was recorded, together with the percentage of each substratum type present. To quantify the substratum, each plot was subdivided into 16 smaller squares using string. Observations both for counting species and for recording the percentage of each substratum type were carried out slowly ( 1 to $3 \mathrm{~min} \mathrm{~m}^{-2}$, depending upon the complexity of the substratum). The frame was gently placed on the bottom in order not to disturb and scatter the fish. The substratum types considered were: sand (S), gravel (G), blocks (BL), flat rock (FR), rockwalls (RW), rock covered by Mytilus edulis (MY), and Posidonia beds (P). Rockwalls with slopes of less than $45^{\circ}$ were classified as flat rock. The percentage and thickness of algal cover per $\mathrm{m}^{2}$ and other types of cover (e.g. Chthamalus stellatus, sponges) were also recorded. Algal cover was quite similar in all the depth intervals in terms of both percentage $($ mean $=83.7 \%, \mathrm{SD}=18.2)$ and species present on the blocks, flat rock, and rockwalls (mainly Asparagopsis armata and Corallina elongata). Algal cover on sand and gravel was negligible. Therefore, in the interest of simplifying data treatment, algal cover was not taken as a substratum variable. 
Data analysis. Substratum use by each of the species was established by taking into account the different substratum types used in each $\mathrm{m}^{2}$ plot along each of the transects in which the species was present. A chisquared test was applied to determine whether substratum use by species was proportional to the availability of that substratum type in the environment. To estimate the level of preference for a given substratum type, electivity $(E)$ values were calculated for each type using the equation of Chesson (1983):

$$
E=\frac{\left(r_{i j} / p_{i}\right)}{\sum\left(r_{i j} / p_{j}\right)}
$$

where $r_{i j}$ is the proportion of substratum $j$ used by species $i$ and $p_{j}$ is the proportion of substratum $j$ available in the environment. The value of $E$ ranges from 0 for substrata never used by species $i$ to 1 for exclusive use of the substratum in question by species $i$. Values of around $1 / m$, where $m$ is the number of substratum types, are considered random electivities (Chesson 1983). Therefore, electivity values of 0.1 or lower were considered to reflect a negative preference, electivity values of between 0.1 and 0.15 were considered random and values higher than 0.15 were considered to reflect a positive preference. Electivity values in no case exceeded 0.6.

Consistency of substratum use by each species along the different transects and at the different sampling localities was tested using Kendall's coefficient of concordance and Friedman's rank test to measure the level of significance (Kendall 1962).

An ANOVA by ranks using the non-parametric Kruskal-Wallis test was performed to ascertain whether the densities for the different species differed at the 3 sampling localities (Port de la Selva, Medes Islands, and Blanes). In order to facilitate comparisons between the density values for the 3 localities, the plots at each sampling locality were grouped together by assignment to 1 of 3 categories of substratum type: (1) sand-gravel-Posidonia oceanica beds; (2) blocks; and (3) flat rock - rockwalls - rock covered by Mytilus edulis. One of these 3 substratum types occupied at least $50 \%$ of each plot. Comparison of substratum composition of the plots in each category for each of the sampling localities revealed a high level of similarity $\left(\chi^{2}, p<0.001\right)$, and consequently possible differences in densities were not considered ascribable to differences in substratum type availability.

To test interactions between species pairs, the following 4 approaches were taken:

(1) Substratum overlap based on substratum electiv. ity values (Lawlor 1980, Norton 1991). A chi-squared test was applied to measure overlap in substratum use by species pairs.
(2) The disjunct distribution between species pairs was analysed using data on presence-absence of species within each $\mathrm{m}^{2}$ plot and the results of a 2-by-2 contingency test (Pielou 1969).

(3) In those species pairs which may be competitive when the 2 species coexist (sympatry), niche breadth of the subordinate species can be expected to be narrower than when the species are separated (allopatry). The index of Simpson (1949) was used to calculate niche breadth $(B)$ for each species observed to be sympatric and allopatric in the different plots:

$$
B=\frac{1}{\sum\left(r_{i l}\right)^{2}}
$$

where $r_{i j}$ is the proportion of substratum $j$ used by species $i$.

(4) The last procedure examines variations in niche parameters (breadth and overlap) according to the number of species present along each transect (MacArthur 1972, Pianka 1974, Fox 1981). Niche breadth for each species on each transect was calculated using the formula of Simpson (1949). Niche overlap $(O)$ for all species pairs was calculated using the index of Schoener (1968):

$$
O=1-\sum\left(0.5\left|p_{i k}-p_{j k}\right|\right)
$$

where $p_{i k}$ is the proportion of substratum $k$ used by species $i$ and $p_{j k}$ is the proportion of substratum $k$ used by species $j$. Both niche breadth and niche overlap were standardized on the number of available substratum type (Findley \& Findley 1985).

As pointed out by Fox (1981) and Findley \& Findley (1985), a decrease in niche breadth and niche overlap with species richness may be indicative of diffuse competition within a community. An inverse trend or the absence of any clearly defined trend is suggestive of an unsaturated community with a low level of competition.

\section{RESULTS}

A total of 1378 specimens belonging to 17 species (4 gobies, 12 blennies, and 1 threefin blenny) were recorded. Only the 11 most abundant species ( $\geq 20$ individuals in all on all 28 transects combined) were included in the analyses: Gobius auratus Risso, $G$. buchichi Steindachner, G. cobitis Pallas, Aidablennius sphynx (Valenciennes), Lipophrys trigloides (Valenciennes), L. Canevai (Vinciguerra), Parablennius gattorugine (Brünnich), P. incognitus (Bath), P. rouxi (Cocco), P. sanguinolentus (Pallas), and Tripterygion tripteronotus (Risso). The densities of the remaining 
species, G. geniporus Valenciennes, $L$. pavo (Risso), $L$. dalmatinus (Steindachner \& Kolombatovic), P. zvonimiri (Kolombatovic), P. tentacularis (Brünnich), and $P$. pilicornis (Cuvier), were very low (less than 20 individuals in total on all the transects combined), and they were therefore excluded from the analyses. Other species closely associated with the substratum belonging to other families (e.g. Clinidae, Gobiesocidae) were also recorded, but their abundance was also very low (less than 10 individuals in total on all the transects combined) and were likewise not included in the analyses.

Some species (Aidablennius sphynx, Lipophrys canevai, L. trigloides, Parablennius sanguinolentus, and Gobius cobitis) were recorded only at depths shallower than $5 \mathrm{~m}$. P. incognitus, Tripterygion tripteronotus, and $G$. buchichi were mainly present in the first depth interval but were also found in deeper intervals. $P$. gattorugine occurred in all intervals, whereas $P$. rouxi and $G$. auratus were recorded only at depths greater than $5 \mathrm{~m}$. L. canevai was found only in holes, and $A$. sphynx, $P$. incognitus, and $P$. rouxi in both holes and crevices and on rock surfaces. The use of holes by the latter species varied with locality: in Blanes, where the substratum was devoid of holes, they were observed both in crevices and on rock surfaces, whereas in Port de la Selva and the Medes Islands they also dwelled in holes. The remaining species were observed on the surfaces of the different substrata, though they were occasionally also found in crevices or the spaces between blocks. In those species in which adult males and females and immature males had different colour patterns, namely $L$. canevai and $T$. tripteronotus (Wirtz 1978, Zander 1986a, b, Abel 1993), mature males accounted for less than $7 \%$ of the total number of individuals recorded.

Recruits of the following species were observed during the sampling period: Aidablennius sphynx, Parablennius incognitus, $P$. rouxi, $P$. sanguinolentus, Tripterygion tripteronotus, and Gobius auratus.

\section{Substratum use}

According to Friedman's rank test $(p<0.05)$, the substratum type used by all the species was similar on all transects and at all localities, except in the case of Parablennius rouxi (Table 1).

Use of substratum type was not proportional to its availability in the environment for any of the species $\left(\chi^{2}\right.$, $p<0.001$ ), but all the species did display a clear preference for some substrata (Fig. 2). Gobius auratus and G. buchichi preferred areas consisting of blocks with a high proportion of sand. G. cobitis, Parablennius rouxi, and $P$. sanguinolentus preferred areas in which blocks predominated. $P$. incognitus, Lipophrys canevai, $L$.
Table 1. Intersite consistency in microhabitat distribution of species using Kendall's coefficient of concordance $(W)$. ns: not significant

\begin{tabular}{|lcc|}
\hline & $w$ & $\mathrm{p}$ \\
\hline Aidablennius sphynx & 0.57 & $<0.05$ \\
Lipophrys canevai & 0.89 & $<0.01$ \\
L. trigloides & 0.89 & $<0.01$ \\
Parablennius gattorugine & 0.56 & $<0.01$ \\
P. incognitus & 0.82 & $<0.01$ \\
P. rouxi & 0.07 & $\mathrm{~ns}$ \\
P. sanguinolentus & 0.44 & $<0.05$ \\
Tripterygion tripteronotus & 0.33 & $<0.05$ \\
Gobius auratus & 0.72 & $<0.01$ \\
G. buchichi & 0.73 & $<0.01$ \\
G. cobitis & 0.49 & $<0.05$ \\
\hline
\end{tabular}

trigloides, and Tripterygion tripteronotus preferred areas of rockwall and, to a lesser extent, areas of flat rock and rock covered by Mytilus edulis. Aidablennius sphynx inhabited areas of flat rock and rockwall, while $P$. gattorugine was present both in areas with blocks as well as in areas of rockwall and flat rock.

No significant differences $\left(\chi^{2}, p<0.001\right)$ were observed in use of substratum type and depth between recruits and adult specimens of Aidablennius sphynx, Parablennius incognitus, $P$. rouxi, $P$. sanguinolentus, Tripterygion tripteronotus, and Gobius auratus.

\section{Differences in species number and abundance}

The $0-1 \mathrm{~m}$ depth interval contained the largest number of species per transect $(x=5.3, \mathrm{SD}=2.4)$ and the highest density values (ind. $\mathrm{m}^{-2}, x=2.5, \mathrm{SD}=2.1$ ), whereas the $10-11 \mathrm{~m}$ and $15-16 \mathrm{~m}$ intervals had the lowest values (no. of species, $x=1.2, \mathrm{SD}=1.2$; density, $x=0.24, \mathrm{SD}=0.51$ )

The Kruskal-Wallis test revealed significant differences in abundance for many species on comparing the density values for the 3 localities. With the exception of Parablennius rouxi, the rest of the species were significantly less abundant in the Medes Islands than at Port de la Selva and Blanes. Lipophrys canevai was distinctly less abundant at Blanes than at Port de la Selva. Gobius auratus was more abundant at Port de la Selva than at the other 2 localities (Table 2).

\section{Species interactions}

The mean interspecific overlap values for substratum use based on the electivity values for the different substratum types were high $(p<0.05)$ in 7 species pairs (Table 3). 

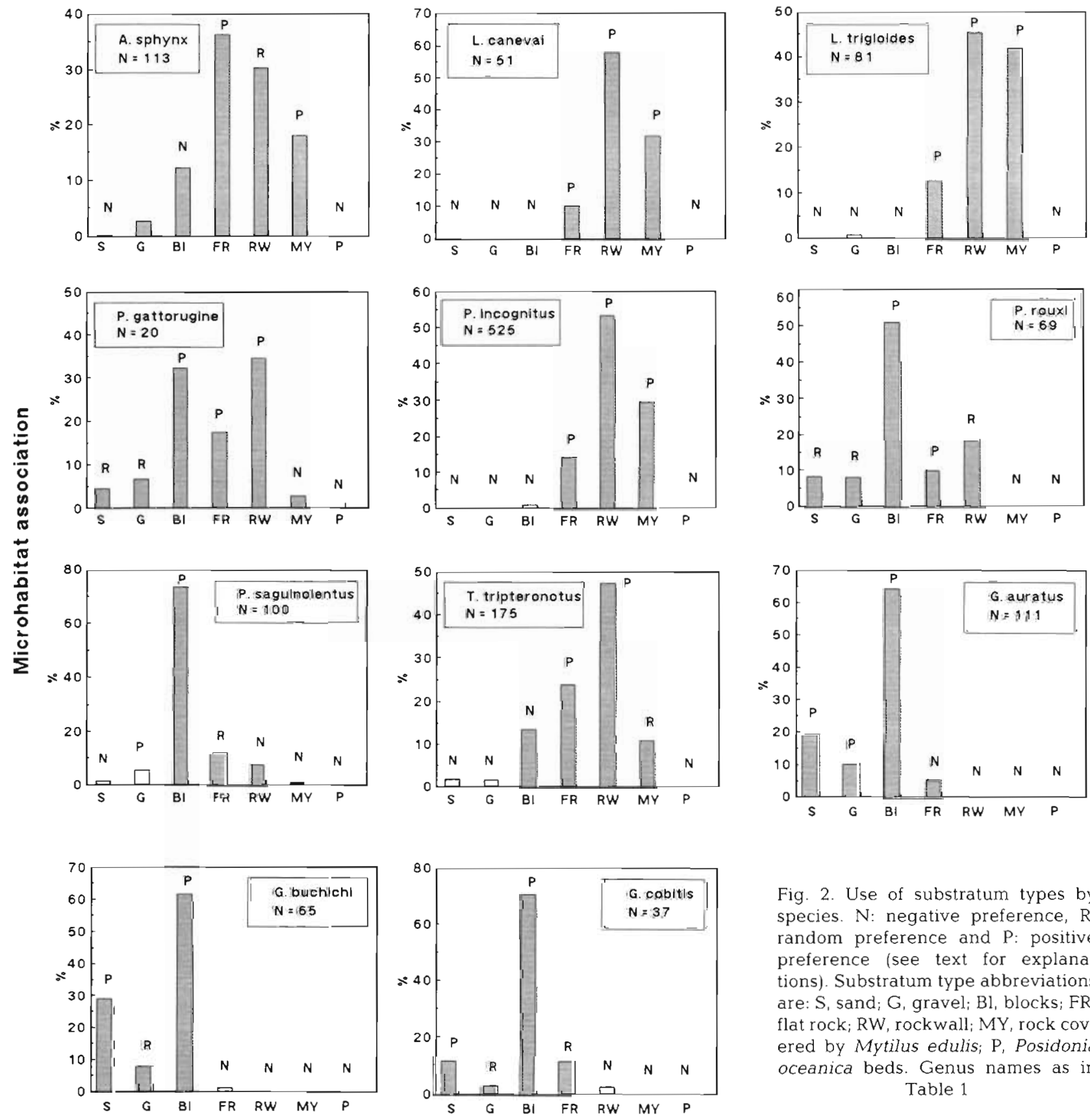

Fig. 2. Use of substratum types by species. N: negative preference, $R$ random preference and $P$; positive preference (see text for explanations). Substratum type abbreviations are: $S$, sand; $G$, gravel; $B$ l, blocks; FR flat rock; RW, rockwall; $M Y$, rock covered by Mytilus edulis; P, Posidonia oceanica beds. Genus names as in Table 1

\section{Habitat type}

Co-occurrence values for species pairs based on the presence and absence data for each $\mathrm{m}^{2}$ plot were positive in 7 species pairs and negative in 3 species pairs (Table 4). The negative co-occurrence values, indicative of disjunct distributions, included Parablennius incognitus and $P$. rouxi, $P$. incognitus and Gobius buchichi, and $P$. incognitus and $G$. cobitis.

Lower niche breadth values for species pairs in plots in which they were sympatric as compared to the values in plots in which they were allopatric were observed for only 9 of the 55 possible species pairs: Aidablennius sphynx-Gobius cobitis, A. sphynx-G. buchichi, A. sphynx-Lipophrys canevai, A. sphynxL. trigloides, $A$. sphynx-Parablennius gattorugine, $A$. sphynx-P. sanguinolentus, L. canevai-L. trigloides, $L$. trigloides $-P$. incognitus and $P$. sanguinolentusTripterygion tripteronotus. Comparing the values for those species pairs, none displayed high overlap 
Table 2. Average density (ind. $\mathrm{m}^{-2}$ ) of each species by locality: Blanes, Medes Islands and Port de la Selva on preferred microhabitats (R) rockwalls - flat rock-rock with Mytilus, (B) blocks, and (S/G) sand-gravel. Level of significance of the differences between localities estimated by ANOVA using the Kruskal-Wallis non-parametric test. n: no. of plots; Avg: average; SD: standard deviation. ns: not significant

\begin{tabular}{|c|c|c|c|c|c|c|c|c|c|c|c|c|}
\hline & \multicolumn{9}{|c|}{ Locality } & \multicolumn{3}{|c|}{ Significance } \\
\hline & \multicolumn{3}{|c|}{ Blanes } & \multicolumn{3}{|c|}{ Medes } & \multirow{2}{*}{$\mathrm{n}$} & \multicolumn{2}{|l|}{ Port } & \multirow{2}{*}{$\begin{array}{l}\text { Blanes/ } \\
\text { Medes }\end{array}$} & \multirow{2}{*}{$\begin{array}{c}\text { Blanes/ } \\
\text { Port }\end{array}$} & \multirow{2}{*}{$\begin{array}{c}\text { Medes, } \\
\text { Port }\end{array}$} \\
\hline & $\mathrm{n}$ & Avg & $S D$ & $\mathrm{n}$ & Avg & SD & & & $\mathrm{SD}$ & & & \\
\hline Aidablennius sphynx $(\mathrm{R})$ & 51 & 0.76 & 1.22 & 124 & 0.14 & 0.42 & 152 & 0.24 & 0.55 & $<0.001$ & $<0.001$ & ns \\
\hline Lipophrys canevai (R) & 51 & 0.04 & 0.20 & 124 & 0.10 & 0.33 & 152 & 0.25 & 0.76 & ns & $<0.05$ & $\mathrm{~ns}$ \\
\hline L. trigloides $(\mathrm{R})$ & 51 & 0.26 & 0.44 & 124 & 0.02 & 0.20 & 152 & 0.51 & 0.88 & $<0.001$ & ns & $<0.001$ \\
\hline Parablennius incognitus ( $\mathrm{R})$ & 51 & 1.96 & 1.78 & 124 & 0.89 & 0.01 & 152 & 2.09 & 1.68 & $<0.001$ & ns & $<0.001$ \\
\hline P. rouxi $(\mathrm{B})$ & 18 & 0.06 & 0.22 & 54 & 0.33 & 0.57 & 79 & 0.14 & 0.36 & $<0.05$ & ns & ns \\
\hline P. sanguinolentus $(\mathrm{B})$ & 26 & 1.04 & 1.25 & 54 & 0.28 & 0.52 & 29 & 1.28 & 0.94 & $<0.01$ & ns & $<0.001$ \\
\hline Tripterygion tripteronotus $(\mathrm{R})$ & 70 & 1.02 & 1.01 & 195 & 0.14 & 0.29 & 200 & 0.49 & 0.77 & $<0.001$ & $<0.001$ & $<0.001$ \\
\hline G. auratus (B) & 18 & 0.0 & 0.0 & 76 & 0.16 & 0.40 & 224 & 0.65 & 0.56 & $<0.001$ & $<0.001$ & $<0.02$ \\
\hline G. buchichi (S/G) & 43 & 0.54 & 1.57 & 62 & 0.35 & 0.30 & 6 & 0.0 & 0.0 & ns & $<0.001$ & $<0.001$ \\
\hline G. cobitis (B) & 27 & 0.08 & 0.26 & 54 & 0.22 & 0.46 & 29 & 0.48 & 0.67 & ns & $<0.01$ & ns \\
\hline
\end{tabular}

according to electivity values for substratum type, negative co-occurrence values, and lower niche breadth values for sympatric relationships.

The slope of the regression line for niche breadth and species richness was negative but not significant $\left(\mathrm{r}^{2}=0.228, \mathrm{p}>0.05, b=-0.011 \pm 0.009\right)$.

The relationship between niche overlap and species richness was similarly nonsignificant $\left(r^{2}=0.002, p>0.05, b=0.001 \pm\right.$ 0.011 ).

\section{DISCUSSION}

The results of the present study indicate that all the species considered displayed a preference for a specific substratum and that preference was unrelated to substratum availability in the environment. The resulting preferential distributions were therefore recorded along all the different transects at all sampling localities and, on the whole, concurred with qualitative findings reported for other locations within the species' distribution ranges (Mediterranean and Northeast Atlantic) (e.g. Miller 1986, Zander 1986a, b). In addition to substratum type, depth was another determining factor affecting the distributions of the species considered. Both species number and species density were distinctly higher for blennies and threefin blennies at depths of less than $1 \mathrm{~m}$, which agreed with results published for the Adriatic Sea (Illich \& Kotrschal 1990). Higher species number and density levels in areas where rock and blocks were abundant was associated with higher substratum complexity as opposed to areas in which sand, gravel, or Posidonia oceanica beds predominated, thus affording more shelter as well as more nesting sites for spawning. The positive relationship between hetero-

Table 3. Species pairs for which substratum type similarity values (chisquared test) were significatively similar. Values were based on electivities calculated using Chesson's index. Table shows the similarity of the first species vs the second species $\left(\mathrm{p}_{1-2}\right)$ and the second species vs the first species $\left(\mathrm{p}_{2-1}\right)$. ns: not significant

\begin{tabular}{|lcc|}
\hline Species pair & $\mathrm{p}_{1 \cdot 2}$ & $\mathrm{p}_{2 \cdot 1}$ \\
\hline Aidablennius sphynx - Tripterygion tripteronotus & $\mathrm{ns}$ & $<0.001$ \\
Gobius auratus - Gobius buchichi & $<0.05$ & $<0.01$ \\
Gobius auratus - Gobius cobitis & $<0.01$ & $\mathrm{~ns}$ \\
Lipophrys canevai - Lipophrys trigloides & $<0.05$ & $<0.05$ \\
Lipophrys canevai - Parablennius incognitus & $<0.05$ & $<0.05$ \\
Lipophrys trigloides - Parablennius incognitus & $<0.05$ & $<0.05$ \\
Parablennius rouxi-Gobius auratus & $\mathrm{ns}$ & $<0.01$ \\
& &
\end{tabular}

Table 4. Species interactions. Sign (positive and negative) and significance of the interaction for each species pair obtained using 2 -way contingency tables for presence and absence of species for each $\mathrm{m}^{2}$ plot. Only those species pairs with a minimum significance level of 0.05 are included

\begin{tabular}{|lcc|}
\hline Species pair & Sign & Significance \\
\hline Aidablennius sphynx - Tripterygion tripteronotus & + & $\mathrm{p}<0.001$ \\
Lipophrys canevai - Parablennius incognitus & + & $\mathrm{p}<0.001$ \\
Lipophrys trigloides - Parablennius incognitus & + & $\mathrm{p}<0.001$ \\
Lipophrys trigloides - Tripterygion tripteronotus & + & $\mathrm{p}<0.05$ \\
Parablennius incognitus - Parablennius rouxi & - & $\mathrm{p}<0.001$ \\
Parablennius incognitus - Tripterygion tripteronotus & + & $\mathrm{p}<0.001$ \\
Parablennius incognitus - Gobius buchichi & - & $\mathrm{p}<0.001$ \\
Parablennius incognitus - Gobius cobitis & - & $\mathrm{p}<0.01$ \\
Parablennius sanguinolentus - Gobius cobitis & + & $\mathrm{p}<0.05$ \\
Tripterygion tripteronotus - Gobius buchichi & + & $\mathrm{p}<0.05$ \\
\hline
\end{tabular}


geneous substratum topography and diversity has been documented previously for other benthic fish communities (Luckhurst \& Luckhurst 1978). The gobiids, in contrast, did not exhibit any clear tendency in the depth range considered, but certain researchers (Miller 1986, García-Rubies 1994) have reported an increase in both the number and density of Mediterranean gobiid species with depth. On the contrary, Costello (1992), studying the densities of gobies in southwest Ireland, did not find this trend: both species number and density were higher in shallow waters.

Although species presence on the different substratum types was similar at all 3 sampling localities, there were some significant differences in density. The lower density levels recorded for most species in the Medes Islands may be associated with the presence of larger numbers of predators. The Medes Islands are a protected marine reserve where levels of predator abundance are much higher than the levels reported in unprotected areas (García-Rubies \& Zabala 1990). Highly abundant species in that locality (e.g. Diplodus sargus, Serranus cabrilla) often prey upon blennies when feeding at the surface in areas where blocks, rockwalls, and Mytilus edulis are prevalent (pers. obs.). If more detailed studies bear out this negative relationship, it will show that some of the benefits associated with marine reserves (Roberts \& Polunin 1991 and references cited therein) may not be applicable to all fish communities.

On the other hand, Lipophrys canevai tends to inhabit holes excavated in the rock by the endolithic bivalve Lithophaga lithophaga (Koppel 1988) or formed by erosion. The species was virtually absent in the Blanes area, where the nature of the rock prevents the formation of holes exploitable by this species. This suggests that the number of holes is a limiting factor for the abundance of that species.

The results of this study also indicate that interspecific space competition may not be a major determining factor affecting community structure but rather that most species occupy the substratum without any adverse influence on the others. Both the disjunct distributions and the changes in niche breadth values for sympatric and allopatric distributions of species pairs reflect low levels of potentially competitive interactions.

The failure to establish a relationship between niche breadth and niche overlap and species richness may suggest the existence of an unsaturated community (Fox 1981, Findley \& Findley 1985) despite the marked territorial nature of blennies and threefin blennies. The low level of saturation may be related to the small size of the territory defended by the males of some of the most abundant species (Parablennius incognitus and Lipophrys canevai), ranging between 7 and $11 \mathrm{~cm}$ in radius (Koppel 1988). Density levels for males were low (around $7 \%$ of the population sampled) for other species (e.g. Tripterygion tripteronotus) in which the breeding male defends a larger territory (Wirtz 1978, De Jonge \& Videler 1989), hence the effect of territorial competition among such males is low for the population as a whole.

As already pointed out above, observational studies are not appropriate to properly establish the existence of competition (Connell 1983, Hastings 1987). Whether or not competition for space is a major organizing force underlying the structure of this assemblage should be confirmed by means of experimental studies (Hurlbert 1984). However, the results presented here suggest that experimentation will probably not reveal high levels of interspecific competition among the species considered.

The important role of substratum type on the structure of the community considered would appear to exert an effect right from the time of settlement. In fact, recruits of the most abundant species were observed on the same substratum types and at the same depths as the adults. The role of habitat in limiting recruitment has been reported for different communities (Connell \& Jones 1991, Jones 1991, Buchheim \& Hixon 1992). Nevertheless, further work needs to be carried out in the future to analyze the influence of both substratum type and other factors regulating settlement of new recruits and their effect on the structure of the adult population (see Sale 1991 and references cited therein). These studies will improve our understanding of the mechanisms regulating this littoral community in the Mediterranean Sea.

Acknowledgements. I thank A. García-Rubies and E. Sala for their assistance in collecting data. This manuscript benefited from input from M. P. Olivar, A. Gordoa, P. Abelló and R. Sacks, who also prepared the English version. This research was funded by the Comision Interministerial de Ciencia y Tecnología (CICYT, MAR91-0860).

\section{LITERATURE CITED}

Abel, E. F. (1993). Colouration phenomena of Mediterranean blennies (Pisces, Blenniidae). P.S.Z.N. I: Mar. Ecol. 14: 291-312

Alatalo, R. V., Gustafsson, L., Lundberg, A. (1986). Interspecific competition and niche changes in tits (Parus spp.): evaluation of ronexperimental data. Am. Nat. 127: $819-834$

Bennett, W. A. (1990). Scale of investigation and the detection of competition: an example from the house sparrow and house finch introductions in North America. Am. Nat. 135: $725-747$

Buchheim, J. R., Hixon, M. A. (1992). Competition for shelter holes in the coral-reef fish Acanthemblemaria spinosa Matzelaar. J. exp. mar. Biol. Ecol. 164: 45-54

Chesson, J. (1983). The estimation and analysis of preference and its relationship to foraging models. Ecology 64: $1297-1304$ 
Cohen, J. (1977). Statistical power analysis for the behavioral sciences. Academic Press, New York

Connell, J. H. (1983). On the prevalence and relative importance of interspecific competition: evidence from field experiments. Am. Nat. 122: 661-696

Connell, S. D., Jones, G. P. (1991). The influence of habitat complexity on postrecruitment processes in a temperate reef fish population. J. exp. mar. Biol. Ecol. 151 271-294

Costello, M. J. (1992). Abundance and spatial overlap of gobies (Gobiidae) in Lough Hyne, Ireland. Environ. Biol. Fish. 33: $239-248$

De Jonge, J., Videler, J. J. (1989). Differences between the reproductive biologies of Tripterygion tripteronotus and $T$. delaisi (Pisces, Perciformes, Trypterygiidae): the adaptive significance of an alternative mating strategy and a red instead of a yellow nuptial colour. Mar. Biol. 100: 431-437

Doherty, P. J. (1991). Spatial and temperature patterns in recruitment. In: Sale, P. F. (ed.) The ecology of fishes on coral reefs. Academic Press, New York, p. 261-292

Findley, J. S., Findley, M. T. (1985). A search for pattern in butterflyfish communities. Am. Nat. 126: 800-816

Fox, B. J. (1981). Niche parameters and species richness. Ecology 62: $1415-1425$

García-Rubies, A. (1994). Poblacions de peixos litorals sobre substrat rocos. Factors que influexen la seva distribució. Ph.D. thesis, Univ. of Barcelona

García-Rubies, A., Zabala, M. (1990). Effects of total fishing prohibition on the rocky fish assemblages of Medes Island marine reserve (NW Mediterranean). Scientia mar. 54: $317-328$

Gibson, R. N. (1969). The biology and behaviour of littoral fish. Oceanogr. mar. Biol A. Rev. 7: 367-410

Grossman, G. D. (1982). Dynamics and organization of a rocky intertidal fish assemblage: the persistence and resilience of taxocene structure. Am. Nat. 119: 611-637

Hastings, A. (1987). Can competition be detected using cooccurrence data? Ecology 68: 117-123

Hixon, M. A. (1991). Predation as a process structuring coral reef fish communities. In: Sale, P. F. (ed.) The ecology of fishes on coral reefs. Academic Press, New York, p. $475-500$

Hurlbert. S. H. (1984). Pseudoreplication and the design of ecological field experiments. Ecology 54: 187-211

Illich, I. P., Kotrschal, K. (1990). Depth distribution and abundance of northern Adriatic littoral rocky reef blennioid fishes (Blenniidae and Tripterygion). P.S.Z.N. I: Mar. Ecol. 11: $277-289$

Jones, G. P. (1991). Postrecruitment processes in the ecology of coral reef fish populations: a multifactorial perspective In: Sale, P. F. (ed.) The ecology of fishes on coral reefs Academic Press, New York, p. 294-327

Kendall, M. G. (1962). Rank correlation methods. Charles Griffin, London

Koppel, V. H. (1988). Habitat selection and space partitioning among two Mediterranean blenniid species. P.S.Z.N. I Mar. Ecol. 9: 329-346

Kotrschal, K. (1988). Blennies and endolithic bivalves: differential utilization of shelter in Adriatic Blenniidae (Pisces Teleosteij. P.S.Z.N. I: Mar. Ecol. 9: 253-269

Kotrschal, K., Reynolds, W. W. (1982). Behavioral ecology of northern Adriatic reef fishes in relation to seasonal temperature regimes. Contrib. mar. Sci. 25: 99-106

Lawlor, L. R. (1980). Overlap similarity and competition coefficients. Ecology 61: 245-251

Llewellyn, J. B., Jenkins, S. H. (1987). Patterns of niche shift in mice: seasonal changes in microhabitat breadth and overlap. Am. Nat. 129: 365-381

Luckhurst, B. E., Luckhurst, K. (1978). Analysis of the influence of the substrate variables on coral reef fish communities. Mar. Biol. 49: 317-323

MacArthur, R. H. (1972). Geographical ecology. Harper \& Row, New York

Medialdea, J., Maldonado, A., Alonso, B., Díaz, J. I., Ercilla, G., Farràn, M. (1994). Mapa geológico de la plataforma continental espanola y zonas adyacentes $n^{\circ} 25$, Hoja Rosas. ITGE, Madrid

Medialdea, J., Maldonado, A., Díaz, J. I., Escutia, C., Farràn, M., Giro, S., Serra, M. (1989). Mapa geológico de la plataforma continental española y zonas adyacentes $n^{\circ}$ 35-42E, Hoja Barcelona. ITGE, Madrid

Miller, P. J. (1986). Gobiidae. In: Whitehead, P. J. P., Bauchot, M. L., Hureau, J. C., Tortonese, E. (eds.) Fishes of the Northeastern Atlantic and the Mediterranean. UNESCO, Paris, p. 1019-1085

Norton, S. F. (1991). Habitat use and community structure in an assemblage of cottid fishes. Ecology 72: 2181-2192

Pianka, E. R. (1974). Niche overlap and diffuse competition. Proc. nati Acad. Sci. 71: 2141-2145

Pielou, E. C. (1969). An introduction to mathematical ecology. Wiley, New York

Roberts, C. M., Polunin, N. V. C. (1991). Are marine reserves effective in the management of reef fisheries? Rev. Fish Biol. Fish. 1: 65-91

Ross, S. T. (1986). Resource partitioning in fish assemblages: a review of field studies. Copeia 1986: 352-388

Roughgarden, J. (1983). Competition and theory in community ecology. Am. Nat. 122: 583-601

Sale, P. F. (1991). Reef fish communities: open nonequilibrial systems. In: Sale, P. F. (ed.) The ecology of fishes on coral reefs. Academic Press, New York, p. 564-596

Santos, R. S., Almada, V. C. (1988). Intraspecific variations in reproductive tactics in males of the rocky intertidal fish Blennius sanguinolentus in the Azores. In: Chelazzi, G., Vannini, M. (eds.) Behavioral adaptation to intertidal life. NATO ASI Series A: Life sciences, Vol. 151. Plenum, New York, p. 421-447

Schoener, T W. (1968). The Anolis lizards of Bimini: resource partitioning in a complex fauna. Ecology 49: 704-726

Schoener, T. W. (1983). Field experiments on interspecific competition. Am. Nat. 122: 240-285

Simpson, E. H. (1949). Measurement of diversity. Nature 163: 688

Strong, D. R. Jr (1983). Natural variability and the manifold mechanisms of ecological communities. A.m. Nat. 122: $623-660$

Wilkins, H. K. A., Myers, A. A. (1992). Microhabitat utilisation by an assemblage of temperature Gobiidae (Pisces: Teleostei\}. Mar. Ecol. Prog. Ser. 90: 103-112

Wilkins, H. K. A., Myers, A. A. (1993). Shelter utilization by Gobius cruentatus and Thorogobius ephippiatus (Teleostei: Gobiidae). J. Fish Biol 43: 763-773

Wirtz, P. (1978). The behaviour of the Mediterranean Tripterygion species (Pisces, Blennioidei). Z. Tierpsychol. 48: $142-174$

Zander, C. D. (1986a). Blenniidae. In: Whitehead, P. J. P., Bauchot, M. L., Hureau, J. C., Tortonese, E. (eds.) Fishes of the Northeastern Atlantic and the Mediterranean. UNESCO, Paris, p. 1096-1112

Zander, C. D. (1986b). Tripterygiidae. In: Whitehead, P. J. P., Bauchot, M. L., Hureau, J. C., Tortonese, E. (eds.) Fishes of the Northeastern Atlantic and the Mediterranean. UNESCO, Paris, p. 1118-1121 